\title{
Self - Questioning Strategy on Reading Comprehension Process
}

\author{
${ }^{1 s t}$ Nur Syamsiah \\ STKIP PGRI MetroState \\ Syamsiahnur13@yahoo.com
}

${ }^{2 n d}$ Zainal Rafli

\author{
${ }^{3 r d}$ Sakura Ridwan \\ State University of Jakarta
}

\begin{abstract}
This study aim to get an indepth understanding of the self-questioning strategy on reading comprehension process. The reading skill is essentially complicated by many things, not just pronunciation, but also involving visual, thinking, psycholinguistic, and metacognitive activities. Research subjects are students of a fifth semester at the English Education Program UIN Raden Intan Lampung. Research design is qualitative research by using ethnography method. Qualitative research with ethnography method is intended to explain the cultural aspects of the implementation of selfquestioning strategy in students' reading process of fifth semester in English education study program, UIN Raden Intan Lampung. The research found a unique cultural theme, namely the use of self-questioning strategy in the process of reading comprehension of students with a pattern of activities that are interrelated and affect. The form of selfquestion in the process of understanding the reading of students is characterized by the many types of questions generated by students during the process of reading comprehension.
\end{abstract}

Keywords: self-question, reading, comprehension, extensive reading, ethnography, cognitive, metacognitive

\section{INTRODUCTION}

The reading skill is essentially complicated by many things, not just pronunciation, but also involving visual, thinking, psycholinguistic, and meta-cognitive activities. As a process of thinking, reading includes word recognition activities, literal comprehension, interpretation, critical reading, and creative understanding.
Reading as a process perceptual, meaning this process contains a social stimulus of meaning and interpretation based on experience about the stimulus and the response that connects meaning with the stimulus or the symbol.

According to Alderson (2000) states that reading is generally seen as an activity that consists of decoding and understanding. Decoding activity refers to word recognition activities whereas comprehension activities consist of activities to parse sentences, to understand sentences in discourse, to construct discourse structures, and to integrate what is understood from discourse by what the reader already knows.

Reading is one of the language skills that need to be developed in foreign language learning especially in learning English before other language skills. The above statement relates to the number and development of technologies such as print media, social media, and so forth in the various languages used in the media, so that reading activities in connection with the acquisition of information and knowledge in important positions.

The ability to understand the text that read is one of the prerequisites in the acquisition of information in an effort to broaden the horizons, understand the concept, self-development as part of the improvement of human resources. Thus, it is not surprising that the development of foreign language skills especially in English should be given special attention. The ability to understand English texts, especially for students has become a necessity because the various references and lecture materials printed in English. From the description above shows the two main contributions in reading the information 
acquisition and use of information. The acquisition of information is an effort to enrich themselves with knowledge and skills while the use of information related to the application of knowledge and skills in the context of professional development, hobby, or scientific writing as well as instructions on the use of certain equipment.

Reading in this case is a preliminary process that acts as a guide, because at the time of reading, students can disclose information. Although in practice, not all students have a high level of reading comprehension even though they are reading in a calm and relaxed atmosphere. Stages of reading in English, students should read by using their second language, although it can lead to complex conditions in reading activities, because of the variety of backgrounds that students have. In this study, focused on the Extensive Reading course in the five semester students in particular, because it has a unique and varied both in learning and in learning activities so that it will bring up and reveal new things in every activity that students do.

Extensive Reading course is aim to develop reading habits and positive attitude of students in reading. In this course, the reading material is adapted to the reading material that the student has and / or the reading material provided by the lecturer. The reading material has been adapted to the level of literacy and reading levels of student, in principle in this course more emphasized on what has been read by students and reading comprehension of the students. Extensive Reading courses have an important role in developing students' critical thinking skills in higher education. According to Grabe in Day and Bamford (1986: 35) that is... discovery and creative thinking are emergent processes where the mind, almost of itself, makes nonobvious connections and relations between previously independent domains of knowledge in the mind person..... Which means that the findings and creative thinking is a process of thinking that comes from thinking itself and create relationships in the realm of knowledge before.
However, the observations of the researchers show that the ability to understand English texts is still inadequate. The existence of various complaints from lecturers, especially lecturers Reading to the still low ability of students in understanding the English text which is an indicator in the course has not been achieved. This shows the gap between the teaching objectives and the results achieved. The gap raises the question of why students still have difficulty in understanding the text, even though it has been trained and equipped with various strategies of understanding the text with sufficient time allocation. Whether the lecturer has been teaching well, does the material and level of difficulty of the text fit the appropriate level, whether the student has a good basics or reading strategy, whether the student has sufficient vocabulary to understand English texts, does the student have a habit of spending time to read, or reading habits of students who less use linguistic ignorance and experience and insight about the theme of the text being read? Factors on how to teach, and the relevance or appropriateness of the material to student maturity can be easily detected or identified through teaching tools or documents created by teachers but the reading habit factor and what happens in a person's mind while reading is still a mystery that needs to be solved.

In addition, reading skill especially in reading comprehension of English is an important skill that must be mastered by learners or students in learning activities, besides other skill abilities. With the ability to read students will be easier to express ideas, provide solutions to a problem, and so that they will succeed in lectures and life. Likewise, the ability is a provision for success in his life, for example succeeding in the world of journalists, analysts, and so on.

As Mackey points out in an educational genius article that the amount of vocabulary for adults depends on the level of education, ranging from 10,000 for people who do not attend college, up to 150,000 for a scientist, while the average student has about 60,000-100,000 words. Fourth, students often use strategies when reading; namely skimming strategy, scanning, 
self-questioning. Skimming is a quick way of reading to get a general idea in the text, in this strategy the reader will see something specific or get an idea generally before he or she is interested to read more deeply. Scanning is a reading technique used by readers to find basic information without reading the text as a whole, usually readers simply see the title, table of contents, and so forth.

Furthermore, self-question is an effective strategy used by students during the process of reading comprehension, according to Schumacker et.al in Shang \& Chien (2010), Selfquestioning strategy is designed to help students effectively understand complex reading demands. According to King, self-questioning strategy is proposed that the focus of questionsgenerated strategy is to let readers' attention fully concentrate on major concepts of the texts, and then to analyze the content with the prior knowledge and to do evaluation during the process of questioning and answering. If readers cannot correctly answer the questions which they generate, it means that readers do not understand the content of the text clearly and deeply. Therefore, through self-questioning use, readers could be aware what they have already known or not after reading. From these two opinions, it can be concluded that the self-question strategy has helped the students in understanding a text and the questions that have been produced can make the reader understand the text content of the reading material, for this reason researchers deepen about the strategy of self-question in the process of understanding readings that occur in students.

Self-questioning is also attributed to the active process of understanding indicated by the ongoing process of the questions and answers during reading (Singer \& Haldorson). The opinion seems to have something to do with Anderson's findings of student-generated research aid that mentions student questions as one of the discussions that helps students to use their understanding of learning materials. In a previous study was Singer's research in his research, he categorized research based on hypotheses on the division of strategies for improvement and comprehension of reading tests. Singer has divided the hypothesis into three categories. The first, related to input stimulus; the second, consent with the centralization of the mediation process on the learning procedure that became the center for the development of cognitive processes for encoding, storing, retrieving information; and the third category, centered on output products.

This study focused on the types of questions generated by students in the implementation of self-questioning strategies in the process of reading comprehension in the fifth semester of English Education, Tarbiyah Faculty and Teacher Training, UIN Raden Intan Lampung.

\section{METHODS}

The purpose of this research is to get an in-depth understanding of the research focus of the self-question strategy in the process of reading comprehension on the fifth semester English Education program at UIN Raden Intan Lampung. In-depth understanding is detailed in the specific purpose of the types of questions generated by students in the activities of selfquestion on the process of reading comprehension

In this research used qualitative approach with ethnography method. Qualitative approach with ethnography method is intended to explain the cultural aspects that exist in the implementation of self-questioning strategy in the process of understanding the reading of students' the fifth semester, English Education Study Program, Tarbiyah Faculty and Teacher Training, UIN Raden Intan Lampung. Ethnography is a method of social science research. This study strongly believes in personal closure, experience, and participation, not just observation, by researchers trained in ethnographic art. These ethnographers often work in multidisciplinary teams. The focal point of his research may include intensive study of culture and language, field or single domain, or combination of historical methods, observations, and interviews. According to Spradley the meaning of ethnographic research "... is the work of describing a culture. The essential core of this activity aims to understand another way of life 
from the native point of view." it means that ethnographic research is a study that attempts to explain the cultural aspect from the point of view of actors.

The procedure of this study refers from Spradley (1979), which includes 12 steps, as follow; a) locating an informants, b) interviewing an informants, c) making an ethnographic record, d)asking description question, e) analyzing ethnographic interview, f) making a domain analysis, g) asking structural question, h) making taxonomic analysis, i) asking question contrast, j) making a componential analysis, k) discovering culture theme, i) writing an ethnographic.

\section{RESULTS AND DISCUSSION}

Self-questioning is a process that continues to ask questions before, during, and after reading that is used by the reader to understand the text. The questions posed are based on the instructions found in the text and are generated to trigger curiosity that focuses the reader's attention on education, understanding, and relationship with the text. This is consistent with the results of a study in the National Reading Panel (2003) which states that selfquestioning is simply a process in which students ask and answer questions while reading. Strategically asking and answering questions while reading helps students with difficulties engaging with text in ways that good readers do naturally, thus improving their active processing of text and their comprehension. Which means self-question is a process where students ask and answer questions when reading. The strategy of asking and answering questions while reading helps students who have difficulties relating to the text, this strategy is done naturally by the reader, so this strategy can improve the process of understanding and their mental activation process. Thus, the self-question strategy is the selection of the right strategy for students of English Education Study Program, UIN Raden Intan Lampung. Now, students spend more time reading than other activities, students are more comfortable discussing what they have learned and looking for other literature if they find discussions that they have not understood and knew beforehand. Students begin to show the positive side of using self-questioning strategies if in class and outside class, they ask a lot of questions when the learning activities take place or even after they leave the class. Several studies have revealed the effectiveness of using selfquestions in the process of reading comprehension.

The use of self-question strategies is also used in various universities or schools. This strategy is used as a solution to facilitate students in understanding a reading. Like research conducted at Payame Noor University (2015) in the country of Iran, it has been revealed that the strategy of self-question as a generative learning strategy for students of English in Iran as a foreign language (EFL) is used in the performance of student reading comprehension. The results showed that the use of self-question strategy had a significant influence on the performance of reading comprehension and students were divided into experimental groups and control groups. Conclusions, significant differences were found in students of higher level of understanding after using the selfquestion strategy in the experimental class compared to female students in the control class. Furthermore, using the self-question strategy at Texas Cristian University (2015), this strategy is used in the process of student reading comprehension. This is because some students need strategies when reading. The results of the study have shown that there is a significant influence between self-question strategy and students' understanding of a reading.

The self-question strategy in Indonesia is also used as a strategy to help students or students in the area understand a reading. As was done at IKIP Gunung Sitoli (2009), this strategy is used because it is easy to prepare and implement in improving reading comprehension skills. As a result of this study, a very effective self-question strategy was used to improve students' understanding of the reading. Thus, the self-question strategy is effective to develop students 'ability to understand a reading so that the activity has changed students' thinking patterns and reading styles. The students are 
more active and communicative when they are in class or outside the classroom

Based on the result of the studies have been described, in this section will explain some of the findings, domain analysis, taxonomic analysis, component analysis, and analysis of cultural themes.

\subsection{Domain Analysis}

Domain analysis is collected data that is field, observation, and descriptive interviews that generate list of identified domains. In connection with the findings of domains that need to be investigated further, namely the type of questions that you produce by students in the activities of self-question in the process of reading comprehension.

The types of self-question produced by students are questions based on grouping selfquestion into two categories, namely types of cognitive and metacognitive questions, it can be explained that the questions include the results of self-questions for the types of cognitive questions that can help the subject research to understand the reading material that has been given to them, the self-question, the type of metacognitive questions that have helped directly and helped them in the process of thinking and focus, and the types of cognitivemetacognitive questions have also helped research subjects to understand reading material. At the same time, able to control their thinking process. When the percentage results are written, it can be said that the type of self-question in the form of cognitive questions, metacognitive questions, combinations of types of cognitive and metacognitive questions.

The types of cognitive questions that are messages of action. The types of single questions (literal, inferential, evaluation, reorganization and personal) were first given, then the students continued with the type of multiple questions (two types of questions) and three types of questions (combination of three types of questions). Furthermore, the questions of metacognitive and cognitive-cognitive types have been described. It is specifically stated that self-question consists of literal questions, inferential questions, personal questions, literal questions, inferential, literal questions, general reorganization, inferential questions, internal reorganization, inferential questions, evaluative, inferential questions, reorganizational and evaluative, metacognitive questions, evaluative, metacognitive questions, and literal, reorganizational, and metacognitive questions.

\subsection{Taxonomy Analysis}

The results of this taxonomic analysis are derived from a number of focused questions as guidelines for structural interviews. The list of focused interview questions, observation data and structural interviews. Findings Types of questions generated by students are obtained from observations, and student documents about the types of questions generated by students of the fifth semester on self-question activities in the process of reading comprehension.

The type of self-question generated by students is a question based on the grouping of self-questions into two categories, namely the types of cognitive and metacognitive questions, it can be explained that the questions include self-question results for types of cognitive questions that can help the research subject to understand the reading material that has been given to them, self-question is a type of metacognitive question that has assisted directly and assisted them in the process of thinking and focus, and the type of cognitive-metacognitive question has also helped the research subject to understand the reading material, and at the same time, is able to control their thinking process. When the percentage is written, it can be said that the type of self-question in the form of cognitive questions, metacognitive questions, a combination of types of cognitive and metacognitive questions.

Here are the types of cognitive questions that constitute a message of action. Single or literal, inferential, evaluation, reorganizational, and personal questions are first provided, then the student goes on with the type of double questions (a combination of two types of questions) and three types of questions (a combination of three types of questions). Furthermore, metacognitive and cognitivemetacognitive type questions have been 
described. It is specifically stated that the selfquestion consists of literal questions, inferential questions of personal questions, literalinferential questions, literal-reorganizational questions, inferential-reorganizational questions, inferential-evaluative questions, inferentialreorganizational-evaluative questions, metacognitive questions, evaluativemetacognitive questions, and literalreorganizational-metacognitive questions.

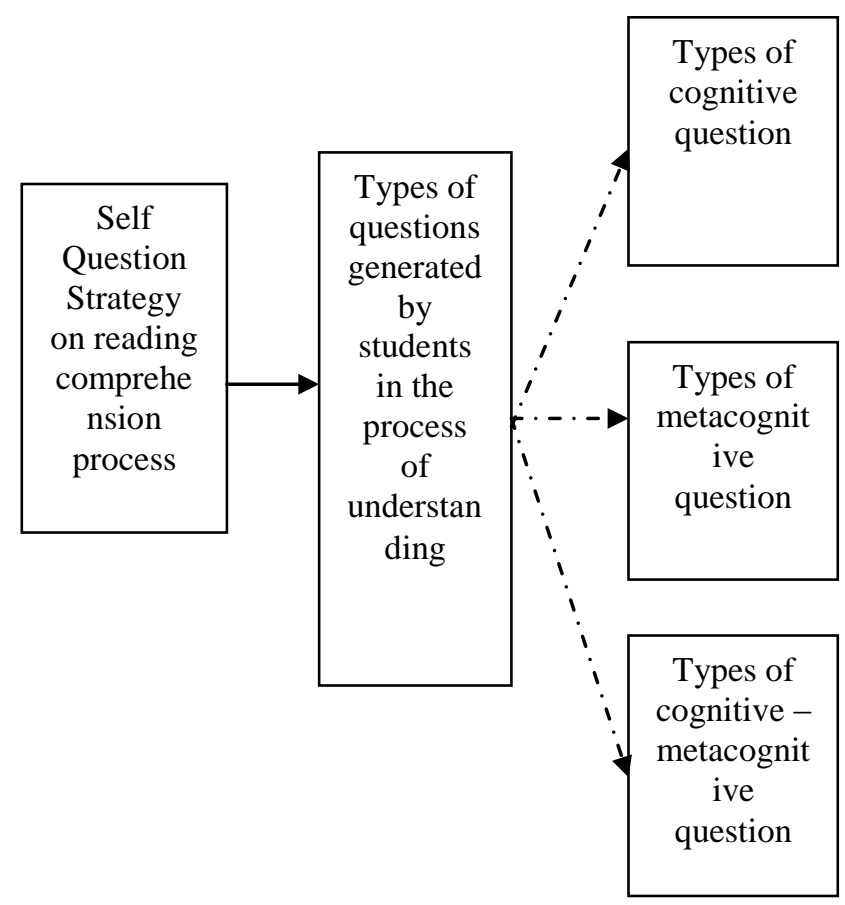

Figure 1 type of questions generated by students in the process of reading comprehension

\subsection{Component analysis}

As has been described in the research findings, the types of questions that have been produced in self-questioning activities consist of cognitive, cognitive, combinations, metacognitive, cognitive-metacognitive questions. Each type will be discussed in the following sub-section.

\subsubsection{Types of Cognitive Questions}

There are several types of cognitive questions resulting from two research subjects in self-questioning activities, namely, literal, inferential, and personal questions. Two other types of questions are the type of reorganization and evaluation, which results in other cognitive combinations or meta-cognitive questions. The combination does not mention clearly in the description of the theoretical framework from previous studies. However, the findings of the study seem to support the possibility of combining different types of cognitive-cognitive or cognitive - meta-cognitive (hybrid question) questions even if they do not receive theoretical explanatory support perfectly. Research as a preliminary research and exploration introduces new findings to be studied and further verification.

\subsubsection{Combination of Cognitive Questions}

Students' self-question activities have resulted in a combination of cognitive questions that are literal, inferential, reorganizational, evaluation or can be drawn as literal-inferential, literal-reorganizational, inferentialreorganizational-evaluation). Literal-inferential questions have been formed when students first search for textual information but have failed to find the information, so they retrieve the relevant knowledge they have in their permanent memory to ask, answer, debate, clarify, confirm, and so on.

\subsubsection{Types of Metacognitive Questions}

There are three metacognitive questions that have been generated by students, and include for this type of understanding in monitoring. Monitoring of questions for understanding has been generated when students make conscious experiments to monitor their understanding or the process of their lack of comprehension while reading. Two other types of questions are not visible because the two research subjects may use different activities to provide planning and evaluation of the effectiveness of reading. From several interviews, they stated explicitly that they were very unfamiliar with the activities directly to generate questions for themselves as they read, and they pointed to the act of use on planning their activities in reading or they repeated their reading (rereading) when the process think they are not effective. 


\subsubsection{Type of Combination of Cognitive -} Metacognitive Questions

There are two types of combinations of cognitive-metacognitive questions generated by students, namely, the types of evaluation questions, metacognitive, literal, reorganizational or can be described in the discussion of the results of this study are metacognitive, literalreorganizational-metacognitive.

\subsection{The result of cultural theme analysis}

In this research, the theme is related to cultural theme. Cultural themes are used as an expressed or implied cognitive principle that occurs over and over again in a number of domains and will form a link between the whole sub-systems of cultural significance. Analysis of cultural themes related to the extensive reading subject, in reading each assignment given by the lecturer, students use the self-question strategy in their understanding process, because the reading comprehension process is done outside the classroom because if this is done in the classroom will spend time, but students in the class often do self-questions when the lecturers give reading assignments, give topics that are brainstorming, and at group presentations. Students produce more literal questions in various functions due to one factor or many factors in generating literal questions, some students can produce most of the process of interpreting, attracting, drawing conclusions, self-confidence, then focusing in the form of writing style. Or other factors that cause the selfquestion strategy in the reading process to be effectively used by students, namely; cognitive aspects, affective aspects, linguistic aspects, metacognitive aspects, inferential aspects, and so on.

In the analysis of cultural themes in this study is to find the relationship between the domain and the overall relationship, which will then be expressed in the form of themes tailored to the focus and sub-focus research. After subsequent component analysis, the theme of cultural analysis is done to find out holistically the cultural background that is being observed and researched.
In addition, the researcher conducted self-immersion or immersion in the field of research, through component analysis of the term references, through the broader domain, searching for similarities between the contrast dimensions, identifying organizing domains, and making diagrams. Then the researchers tried to find a universal theme. The domains of deep concern in this study are about the concept of extensive reading courses, syllabus of extensive reading course, and lectures of extensive reading activities and related to the course of extensive reading with self-question strategy in the process of reading comprehension, the type of selfquestion generated on reading comprehension process.

\section{CONCLUSION}

From the description above it can be concluded that reading skill is essentially a complicated thing involving many things, not just pronunciation, but also involving visual activity, thinking, psycholinguistic, cognitive and metacognitive. As a process of thinking, reading includes word recognition activities, literal comprehension, interpretation, critical reading, and creative understanding. Reading as a process perceptual, meaning this process contains a social stimulus of meaning and interpretation based on experience about the stimulus and the response that connects meaning with the stimulus or the symbol. In this research has found a unique cultural theme, namely the use of self-question strategy in the process of reading comprehension by five semester students in English education study program, UIN Raden Intan Lampung, using the self-question strategy at the time of reading, the students have pattern effective and interrelated activities and influence. The form of self-question in the process of understanding the reading of students is characterized by the many types of questions generated by students during the process of reading comprehension.

\section{References}

Aebersold, Jo Ann dan Marry Lee Field. From Teacher to Reading Teacher Cambridge: Cambridge University Press, 1997. 
Afzali, Katayoon. The Impact of Instructing Self-Questioning in Reading Literary Texts. International Journal of Linguistics, ISSN 19485425, tahun 2012, Vol. 4, No. 2

Alderson J. Charles. Assesing Reading. Cambridge: Cambridge University, 2000, p. 12

Anderson. Efficient Reading: A Practical Guide. Sidney: McGraw-Hill Book Company. 1981.

Baker, Linda, and Brown, Anne L. Cognitive Monitoring. dalam James Flood (Ed) 1984. Understanding Reading Comprehension. Newark: International Reading Association, 1984.

Berkeley, Sheri \& Lisa Marshak, Margo A. Mastropieri, and Thomas E. Scruggs. Improving Student Comprehension of Social Studies Text: A Self-Questioning Strategy for Inclusive Middle School Classes. Remedial and Special Education 32(2), tahun 2011

Brown A. L., \& A. S Palincsar,. Guided, cooperative learning and individual knowledge acquisition. In L. Resnick (Ed.), Knowing, learning, and instruction: Essays in honor of Robert Glaser. Hillsdale, NJ: Lawrence Erlbaum Associates, 1980.

Brown, H. Douglas. Teaching by Principles An Interactive Approach to Language Pedagogy. New York: Longman, 2001.

Burns, Paul C., Betty D. Roe, dan Elinor P. Ross. Teaching Reading in Today's Elementary Schools. Boston: Houghton Mifflin, 1996.

Byrnes,J. \& J. T Guthrie. Prior conceptual knowledge and textbook search. Contemporary Educational Psychology. Jurnal Published. Tahun 1992. Vol. 17, No. 1, h. 186.

Chaer, Abdul \& Leonie Agustina. Sosiolinguistik: Perkenalan Awal. Jakarta: Bhineka Cipta, 2009.

Clark, Donald D. Deshler., Jean B. Schumaker, Gordon R. Alley, Michale M. Warner. Visual Imagery and Self-Questioning: Strategies to Improve Comprehension of Written Material. Journal of Learning Disablities, Volume 17, Number 3, March 1984. copyright@2001 all right reserved

Clark, Herbert H. and Eve V. Clark. Psychology and Language. New York: Harcout Brace Jovanovich, 1997.
Cox, Carole \& James Zarrillo. Teaching Reading with Children's Literature. New York: Macmillan Publishing Company, 1993.

Cresswell, Jhon W. Eduactional Research: Planning, Conducting, and Evaluating Quantitative and Qualitative Research. Ney Jersey: Person Education, Inc, 2012.

Creswell, John W. Qualitative Inquiry and Research Design Choosing Among Five Tradition. London: Sage Publication Inc, 2010.

Day, Richard R. dan Julian Bamford. Extensive Reading in the Second Language. Cambridge: Cambridge University Press, 1998.

Farr, B. Reading: What Can be Meassured? Deleware: International Reading Association. 1969.

Fitzgerald, Jil. English as Second Language Learner's Cognitive Reading Process: A review of Research in The United States. Review of Educational Research. Unpublised journal. Vol. 65, No. 2 tahun 1995. h. 145-190.

Flavell, et. Al. Cognitive Development. Engle Wood Cliffs: Prentice Hall International, Inc, 1993.

Gall, Meredith D, \& Joyce P. Gall, \& Walter R. Borg. Educational Research: An Introduction. Boston: Pearson Education, 2003.

Genevieve, Manset-Williamson, Michael Dunn, Rebecca Hinshaw, \& Jason M. Nelson. The Impact Of Self-Questioning Strategy Use On The Text-Reader Assisted Comprehension Of Students With Reading Disabilities. International Journal of Special Education, Volume 23 Nomor 1 Tahun 2008

Gleason, Jean Barko dan Nan Bernstein Ratner. Psycholinguistics. Forth Worth: Harcourt College Publisher, 1998.

Goodman, Kenneth. Reading A Psycholinguistic Guessing Game. Journal Of Reading Specialist Tahun 1967. Unpublished Journal. Vol. 34, hh. $126-135$

Graesser C. Arthur dan Person, Natalie K. Question Asking During Tutoring American. Educational Research Journal. Tahun 1994, Vol, 31 No. 1. h. 112

Grellet dalam Rouai Souhila (disertasi). The Use of Reading in Improving Reading Comprehension. University Kasdi Merbah 
Ouargla: Faculty of Letters and Languages Department of Foreign Languages English Section, 2013/2014.

Grellet, Francoise. Developing Reading Skills: Practical Guide to reading Comprehention. Yogyakarta: UPP IKIP Yogyakarta, 1981.

Harris, D. Testing as a Second Language. Hongkong: Tata McGraw-Hill Publishing.1977.

Harris. A. J \& E. ${ }^{\mathrm{R}}$. Sipay. How to Increase Reading Ability. New York: Longman. 1980

Henry Guntur Tarigan. Membaca Sebagai Suatu Keterampilan Berbahasa. Bandung: Angkasa, 1987.

Huff, Sarah dalam Artikel Self Question and Reading Comprehension terdapat pada Readworks,org. The Solution To Reading Comprehension, in All Right Reserved 2015

Johnson, An Introduction to Foreign Language Learning and Teaching. London:Longman, 2001.

Kenneth Goodman. The Reading Process. Dalam Carrel, Patricia L (Ed), Interactive Approaches to Second Language Reading. New York: Cambridge University Press.1995.

King, James R. Shirley Biggs and Sally Lipsky. Students' Self-Questioning And Summarizing As Reading Study Strategies. Unpublished Journal. Journal of Reading Behavior 1984, Volume XVI, No. 3

Lapp, Diane, Flood, dkk. Content Area Reading and Learning. Boston: Allyn and Bacon, 1996.

Mackey, W. F. Language teaching analysis. London: Longman. 1965.

Marshall, Catherine and Gretghen B. Rossman, Designing Qualitative Research, Newbury Park: Sage Publication Inc, 1989.

Matlin, M. W. Cognition. Orlando: Harcourt Brace \& Company, 1998.

McCathy, Michael. Discourse Analysis for Language Teacher. Cambridge: Cambridge University, 1991.

Moleong, Lexy J. Metodologi Penelitian Kualitatif. Bandung: Remaja Rosdakarya, 2000.

Mostow, Jack \& Wei Chen. Generating Instruction Automatically for the Reading Strategy of Self-Questioning” . Project LISTEN, School of Computer Science, Carnegie Mellon University, Tahun 2009.
National Reading Panel. Teaching children to read: An evidence-based assessment of the scientific research literature on reading and its implication for reading instruction ( $2^{\text {nd }}$ Edition). Washington, DC: National Institute of Child Health and Human Development and U. S. Department of Education. Tahun 2003

Nunan, Davdi. Languange Teaching Methodology a Text. Sydney: Prentice Hall International, 1998.

Nunan, David. Designing Tasks for the Communicative Classroom. Cambridge: Cambridge University Press, 1989.

Robert C. Bogdan \& Sari Knopp Biklen, Qualitative Research for Education: An Introduction to Theory and Methods. (Boston: Allyn and Bacon, Inc. 1982),

Rumelhart, David E.. Schemata: The Building Blocks of Cognition. Dalam Rand J. Spiro. 1980. Theoritical Issues in Reading Comperehension. Hilsdale: Lawrence Elbaum, Associates: Publisher, 1985.

Safarpoor Leila, \& Saeed Ghaniabadi, \& Asghar Moulavi Nafchi. The Effect of the SelfQuestioning Strategy as a Generative Learning Strategy on Iranian Intermediate EFL Learners' Reading Comprehension. The Asian Journal of English Language \& Pedagogy ISSN 2289-8689 / e-2289-8697 Vol 3, (2015) 66-87

Schmidt H. G.., De Volder, M. L., De Grave., W. S., Moust, J. H. C., \& Patel, V. L. Explanatory models in the processing of science tests: The role of prior knowledge activation through small-group discussion. Journal of Educational Psychology, Tahun 1998, Vol. 81, 610-619. h. 180

Shang, Hui-Fang \& I-Ju Chang-Chien. The Effect of Self-Questioning Strategy on EFL Learners' Reading Comprehension Development. Taiwan: I-Shou University, The International Journal of Learning Volume 17, Number 2, 2010, http://www.LearningJournal.com, ISSN 1447-9494l) pp. 42

Singer H. Active Comprehension: From Answering to Asking Questions. Reading Teacher. Published on journal, tahun 1978. Vol, 31. p. 901-908. 
Singer,M. \& Halldorson, M. Constructing and validating motive bridging inferences. Cognitive Psychology. Jurnal Published, tahun 1996. Vol. 30, No.1, h. 1-38

Smith, C. Teaching in Secondary School Content Subjects: A Book Thingking Process. New York: Holt, Rinehart, and Winston. 1978.

Smith, Frank. Understanding Reading New York: Holt, Rinehart, Winston, 1982.

Spradley, James P. Participant observation. New York: Holt Rinehart \& Winston, 1980.

Spradley,James P. The Ethnographic Interview. New York: Holt Rinehart \& Winston, 1979. Pp. 45-217; 185-186

Tarigan, Membaca Sebagai Suatu Keterampilan Berbahasa (Bandung: Angkasa, 2008),

Telaumbanua, Yasminar Amaerita. SelfQuestioning Strategy to Improve Reading Comprehension Skills of the Second Semester Students of the English Department in IKIP Gunungsitoli. Jurnal Didaktik, Jurnal Ilmiah Pendidikan, Humaniora, Sains, dan Pembelajaranya. Volume 3, Nomor 2, Oktober 2009

Vacca, Jo Anne, dkk. Reading and Learning to Read. Illinois: Scott, Foresman and Company, 1987.

Wainwright, Gordon. Speed Reading Better Recalling. Jakarta: Gramedia Pustaka Utama, 2006.

Wong, Bernice Y.L. Self-question Instructional Research: A Review, Review of Educational Research. Unpublished Journal. Tahun 1985. Vol, 55, No. 2. h. $227-268$ 